\title{
ANTISOCIAL BEHAVIOR AND ALCOHOL CONSUMPTION BY SCHOOL ADOLESCENTS ${ }^{1}$
}

\author{
Karla Selene López García ${ }^{2}$ \\ Moacyr Lobo da Costa Junior ${ }^{3}$
}

López García KS, Costa Junior ML. Antisocial behavior and alcohol consumption by school adolescents. Rev Latino-am Enfermagem 2008 março-abril; 16(2):299-305.

Adolescence is a vulnerable period and facilitates the start of risk behaviors, for instance the use of drugs. This study aims to describe the differences between antisocial behavior and alcohol consumption according to gender, age and education; as well as to discover the relation between antisocial behavior and alcohol consumption in 1,221 school adolescents from Monterrey - Nuevo Leon, Mexico. The findings reveal differences in antisocial behavior according to gender. Evidences showed that $41.3 \%$ of the students had consumed alcohol at sometime in their lives, and that differences exist in alcohol consumption according to age and education. Finally, the study found positive and significant relations between antisocial behavior and alcohol consumption $\left(r_{s}=.272, p<.001\right)$.

DESCRIPTORS: antisocial; alcoholism; adolescent; antisocial personality disorder

\section{CONDUCTA ANTISOCIAL Y CONSUMO DE ALCOHOL EN ADOLESCENTES ESCOLARES}

La adolescencia se convierte en una etapa de vulnerabilidad y facilitador para el inicio de conductas de riesgo como es el consumo de drogas. Los objetivos del presente estudio fueron: describir las diferencias de la conducta antisocial y consumo de alcohol según sexo, edad y escolaridad; conocer la relación existente de la conducta antisocial con el consumo de alcohol en 1221 adolescentes escolares de Monterrey, Nuevo Léon, México, en relación a los hallazgos encontrados se presentan diferencias de la conducta antisocial por sexo; se destaca que $41.3 \%$ de los estudiantes consumieron alcohol alguna vez en su vida, y existen diferencias de consumo de alcohol por edad y escolaridad. Finalmente se encontró relación positiva y significativa de la conducta antisocial con el consumo de alcohol $\left(r_{s}=.272, p<.001\right)$.

DESCRIPTORES: antisocial; alcoholismo; adolescente; transtorno de personalidad antisocial

\section{CONDUTA ANTI-SOCIAL E CONSUMO DE ÁLCOOL EM ADOLESCENTES ESCOLARES}

A adolescência se apresenta como uma etapa de vulnerabilidade e facilitadora para o início de condutas de risco como o consumo de drogas. Os objetivos do presente estudo foram: descrever as diferenças entre sexo, idade e escolaridade na conduta anti-social e o consumo de álcool e conhecer a relação existente entre a conduta anti-social e o consumo de álcool em 1221 adolescentes escolares de Monterrey, Nuevo León, México. De acordo com os resultados obtidos foram observadas diferenças na conduta anti-social por sexo. Destaca-se que $41,3 \%$ dos estudantes consumiram álcool em algum momento da vida, e houve diferenças de consumo de álcool por idade e escolaridade. Finalmente, encontrou-se uma relação positiva e significativa entre a conduta anti-social e o consumo de álcool $\left(r_{s}=, 272, p<, 001\right)$.

DESCRITORES: anti-social; alcoolismo; adolescente; transtorno da personalidade anti-social

${ }^{1}$ Study extracted from Doctoral Dissertation; ${ }^{2}$ Professor, University Autónoma de Nuevo León, Mexico, e-mail: karla_selene23@yahoo.com.mx; ${ }^{3}$ PhD Professor, University of Sao Paulo at Ribeirao Preto, College of Nursing, WHO Collaborating Center for Nursing Research Development, Brazil, e-mail: mlobojr@eerp.usp.br 


\section{INTRODUCTION}

The consumption of alcohol, tobacco and other drugs is stated as one of the most relevant social problems, both due to the magnitude of the phenomenon and to its personal and social consequences. In the world population, $4.8 \%$ of people consume some kind of drug; besides, more than half the population from America and Europe has already consumed alcohol. According to the World Health Organization and the World Bank in Latin America, alcohol abuse has reached the proportion of $9.7 \%$ of one's healthy days that are eventually lost due to early death or disability ${ }^{(1-2)}$.

The drugs phenomenon is highly complex and presents various causes. Moreover, it does not recognize territorial, social or age limits. In this context, it is worth stressing the new standards of drug consumption among adolescents, as the prevalence of drug consumption over the last few years has been increasing. Due to its evolutionary characteristics, such as the search for personal identity and independence, distancing from family values and emphasis on the need for acceptance by peer groups, adolescence has become a stage of vulnerability that facilitates the start of risk behaviors, such as drugs consumption $^{(3)}$

Over the years, the age at which school adolescents have contact with drugs has been anticipated. In Mexico, evidences show that the consumption of licit drugs starts very early, at around 13 years old and, over the following years, many adolescents also start consuming illicit drugs ${ }^{(4)}$.

In relation to alcohol consumption rates among adolescents, it is reported that around $65.8 \%$ have already used alcohol sometime in their lives, and $35.2 \%$ reported its consumption in the last month. In addition, the National Addiction Surveys [Encuestas Nacionales de Adicciones - ENA] evidence a growing tendency in global consumption prevalence of alcohol over the years. In 1998 and 2002, the prevalence rates for men were $27.0 \%$ and $35 \%$, against $18.0 \%$ and $25.0 \%$ for women, respectively, in the same years. Differences regarding the education level are also pointed out, as it is estimated that $24.4 \%$ of secondary students consumed alcohol in the last month, a proportion that doubles for high school students, reaching $51.7 \%^{(1,4)}$.

Estimates for the present consumption of alcohol, from $26.0 \%$ to $81.0 \%$ (CI95\%, 0.24-0.83), have also been reported by school adolescents from 15 to 17 years old, in countries from Central America (Panama, Costa Rica, Nicaragua, Honduras, El Salvador, Guatemala) and the Dominican Republic ${ }^{(5)}$. On the other hand, studies show that drug consumption is mediated by risk and personal, social, cognitive, emotional and attitudinal protection factors, including difficulties in social competences, interpersonal relationships, the need for acceptance by peers, poor family relationships, favorable attitudes towards the use of drugs and lack of assertiveness ${ }^{(6)}$.

It is worth stressing that the ability to interact with other people is directly related to one's social abilities, which facilitate the establishment of close relationships with people. In these terms, the lack of social abilities may complicate the subject's adaptation to the environment, with consequences that comprehend both difficulties to make friends and the development of antisocial and risk behaviors, such as drugs use ${ }^{(7)}$.

It is acknowledged that poor relationships play a critical role in the development of social abilities and personal feelings, which are essential for personal development, and constitute a key factor in the development of personal identity and independence from the family environment. Adolescents who are socially accepted by their peers receive a reinforcement that improves their adaptation, not only in the social environment, but also in the personal and school areas. Thus, acceptance or popularity among one's peers is connected to prosocial behavior, whereas low acceptance is related to the antisocial type ${ }^{(8)}$

In the literature available on the subject, it is observed that high scores of self-perceived antisocial behavior constitute a predictive factor for the consumption of tobacco and alcohol in adolescence. Nevertheless, several studies have manifested that prosocial, assertive and sociable adolescents are less likely to present behaviors of risk to their health, such as the consumption of licit and illicit drugs, when compared to antisocial adolescents ${ }^{(9)}$.

Experience shows that adolescents constitute a population group that is exposed to the risk of drugs use, which happens due to the relation among several personal and social factors, the development of social competence, not to mention all the changes the adolescents go through in this stage of their lives, in addition to the difficulties to adapt themselves to these changes and the influence of their context. Therefore, 
health personnel, including Nursing professionals, have a leading role in the development of prevention factors, such as the strengthening of social competence, promoting prosocial behaviors and good interpersonal relationships, in order to avoid the consumption of drugs by school adolescents and serious consequences for their health in subsequent stages.

Considering the above, this study aims to 1 ) describe the differences between antisocial behavior and alcohol consumption according to gender, age and education; and, 2) discover the relation between antisocial behavior and alcohol consumption by school adolescents from Monterrey, Nuevo Leon, Mexico.

\section{METHODS}

The present study has a descriptive and correlational design, and aims to describe and observe the relation between antisocial behavior and alcohol consumption concepts. The sample consisted of 1,221 students from the first to the third grade of a secondary school in Monterrey, Nuevo Leon, Mexico, calculated through the statistical package $N$ Query Advisor, Version 4.0, with an error limit estimated at 0.05 and $90 \%$ power. Two instruments were used in the development of the study: 1) Teenage Inventory of Social Skills $\left[\mathrm{TISS}^{(8)}\right.$, 2) Alcohol Use Disorders Identification Test [AUDIT], and a history of the use and dependence of alcohol for adolescents ${ }^{(10)}$.

The $\operatorname{TISS}^{(8)}$ assesses the social competences of adolescents in the relationship with their peers. The inventory comprises two scales that include prosocial and antisocial behaviors. The present study only considered the antisocial scale though. The items are evaluated through a six-point Likert scale, in which their self-description varies from total disagreement to total agreement. The antisocial behavior score is obtained by adding up the values the subjects attribute to the scale items, from a minimum of 20 up to 120 . The final score was converted into rates from 0 to 100 for statistical analysis, which interprets a high score as highly antisocial behavior. This instrument obtained acceptable internal consistency rates $(\alpha=0.87)$.

The AUDIT ${ }^{(10)}$ has been used in populations of adolescents and young people, showing acceptable sensitivity and specificity, helping to identify risk and harmful alcohol consumption, as well as a possible dependence. Its score ranges from 0 to 40 . Finally, alcohol consumption was estimated (History of Alcohol Use and Dependence) by assessing the frequency of alcohol use sometime in life (Global Prevalence), in the last twelve months (Lapsing Prevalence) and over the last month (Present Prevalence), as well as the initial age of alcohol consumption.

The present study complies with the Mexican Law of Regulations for Research in Health. Besides, it received approval from the Ethics and Research Committees of the Celaya School of Nursing and Obstetrics at the University of Guanajuato, and authorization from the educational institutions where the study was developed. Students from the selected institutions were invited to take part in the study and, afterwards, received an informed consent term for one of their parents to sign. Students who did not present the consent signed by one of their parents were excluded from this study.

A group consisting of the researcher, ten Master's students in Nursing Sciences and faculty from the Addictions Prevention Unit of the Nursing School at UANL received previous training for the use of the instruments and was in charge of carrying out all the stages of the data collection procedure, in line with the study purpose. It was gently emphasized that the provided information would be completely anonymous and confidential, as their participation was voluntary.

Descriptive and inferential statistics were used for data analysis, and carried out through SPSS software (STATISTICAL PACKAGE FOR THE SOCIAL SCIENCES, 1999), version 10.0. Descriptive statistics revealed the participants' characteristics through frequencies, proportions, central tendency and variability measures. Finally, rates were obtained for the scale used, and the first purpose of the study was achieved by analyzing the data through MannWhitney's U-Test and Kruskal-Wallis, whereas Spearman's correlation coefficient was used to analyze the second purpose.

\section{RESULTS}

In terms of socio-demographic variables, $54.2 \%$ of the study participants were female and their average age was 13 years old $(S D=0.98)$. The sample was proportional in terms of education level, although $35.7 \%$ were taking the third grade of secondary school. Concerning their occupation, $79.6 \%$ were 
students, and $10.2 \%$ of the students who also work are store or supermarket clerks. According to their family characteristics, over $80 \%$ of the students state that they live with both parents. The adolescents presented an average score of 28 points $(S D=16.16)$ according to the antisocial behavior scale, which uses an interval from 0 to 100 for this evaluation.

In the evaluation of the first study purpose, aiming to describe antisocial behavior differences according to gender, age and education, MannWhitney's U-Test showed gender differences in antisocial behavior, as male students ( $\bar{X}=30.64$, $S D=16.26)$ present higher rates of antisocial behavior than female students ( $\bar{X}=26.44, S D=15.85$ ). The study did not find age and education differences in antisocial behavior ( $p>.05)$.

Regarding the proportion of alcohol consumption by adolescents, a significant result is that over $40.0 \%$ of the students have consumed alcohol sometime in their lives. Likewise, the consumption proportion for the last year was over $20.0 \%$, and $13.3 \%$ consumed the substance in the month before the interview, as Table 1 shows.

Table 1 - Consumption of alcohol by school adolescents

\begin{tabular}{lccccc}
\hline $\begin{array}{c}\text { Variable } \\
\text { Alcohol Consumption }\end{array}$ & & $\boldsymbol{f}$ & $\%$ & $\begin{array}{c}\text { Confidence Level 95\% } \\
\text { Minimum }\end{array}$ & Maximum \\
\hline Sometime in life & Yes & 512 & 41.9 & .39 & .45 \\
& No & 709 & 58.1 & & \\
In the last year & Yes & 427 & 35.0 & .39 & .45 \\
& No & 794 & 65.0 & & \\
In the last month & Yes & 162 & 13.3 & .11 & .15 \\
& No & 1059 & 86.7 & & \\
\hline Source: History of Drugs Consumption &
\end{tabular}

Gender differences were not found in alcohol consumption sometime in life or in the last year. Nevertheless, a statistically significant gender difference was indicated by the alcohol consumption in the last month, in which male students showed a higher consumption proportion (36.6\%) than female students $(27.8 \%)$.

According to the participants' age, the study found statistically significant differences in alcohol consumption sometime in life $\left(\chi^{2}=46.96, p<.001\right)$, in the last year $\left(\chi^{2}=57.12, p<.001\right)$ and in the last month $\left(\chi^{2}=38.13, p<.001\right)$. The greatest proportion of alcohol consumption was indicated by 15 -year-olds.

Table 2 presents the results for alcohol consumption with respect to the adolescents' education, evidencing significant differences in alcohol consumption sometime in life, in the last year and in the last month. These differences are observed according to the proportion of alcohol consumption. In other words, as the secondary school years advance, so does alcohol consumption.

Table 2- Alcohol consumption by adolescents according to education

\begin{tabular}{|c|c|c|c|c|c|c|}
\hline \multirow{3}{*}{ Education } & \multicolumn{4}{|c|}{ Alcohol Consumption } & \multirow{3}{*}{$\chi^{2}$} & \multirow{3}{*}{$\begin{array}{c}\mathbf{P} \\
\text { Rate }\end{array}$} \\
\hline & \multicolumn{2}{|c|}{ Yes } & \multicolumn{2}{|c|}{ No } & & \\
\hline & $f$ & $\%$ & $f$ & $\%$ & & \\
\hline \multicolumn{7}{|c|}{ Once in their lifetime } \\
\hline First grade & 122 & 31.3 & 268 & 68.7 & & \\
\hline Second grade & 171 & 43.3 & 224 & 56.7 & 30.79 & .001 \\
\hline Third grade & 219 & 50.2 & 217 & 49.8 & & \\
\hline \multicolumn{7}{|l|}{ In the last year } \\
\hline First grade & 93 & 23.8 & 297 & 76.2 & & \\
\hline Second grade & 138 & 34.9 & 257 & 65.1 & 40.33 & .001 \\
\hline Third grade & 196 & 45.0 & 240 & 55.0 & & \\
\hline \multicolumn{7}{|l|}{ In the last month } \\
\hline First grade & 29 & 7.4 & 361 & 92.6 & & \\
\hline Second grade & 42 & 10.6 & 353 & 89.4 & 35.81 & .001 \\
\hline Third grade & 91 & 20.9 & 345 & 79.1 & & \\
\hline
\end{tabular}

Source: CDP, History of Drugs Consumption

The types of alcohol consumption among the study participants are presented in Table 3, according to the AUDIT scores. It is observed that $34.7 \%$ (IC95\%, .30-49) present one type of risk alcohol consumption, $14.8 \%(I C 95 \%, .11-.18)$ report symptoms of alcohol consumption dependence, and it is worth stressing that $30.4 \%$ (IC95\%, .26-.35) already manifest damage related to alcohol consumption.

Table 3 - Types of alcohol consumption in school adolescents

\begin{tabular}{llcccc}
\hline \multirow{2}{*}{ Alcohol Consumption (AUDIT) } & $\boldsymbol{f}$ & $\%$ & $\begin{array}{c}\text { Confidence Interval 95\% } \\
\text { Minimum }\end{array}$ & Maximum \\
\hline Sensible & No risk & 286 & 65.3 & .30 & .49 \\
Drinking & Risk Consumption & 152 & 34.7 & & \\
& Lack of dependence & 373 & 85.2 & & \\
Dependence & Start of dependence & 65 & 14.8 & .11 & .18 \\
& Lack of damage & 305 & 69.6 & .26 & .35 \\
Damage & Presence of damage & 133 & 30.4 & & \\
& & & & & \\
\hline
\end{tabular}

Source: AUDIT - $\mathrm{n}=1221$

In the analysis of the second purpose of the study, which aimed to discover the relations between adolescent antisocial behavior and alcohol consumption, as presented in Table 4, Spearman's correlation coefficient found a positive and significant relation between antisocial behavior and alcohol consumption $\left(r_{s}=.272, p<.001\right)$. This result indicates that the higher the antisocial behavior score, the greater the alcohol consumption by school adolescents. 
Table 4 - Spearman's Correlation Coefficient for the study variables $\left(p^{*}\right)$

\begin{tabular}{cc}
\hline Variable & Alcohol Consumption (AUDIT) \\
\hline \multirow{2}{*}{ Antisocial Behavior Rate } & $.272^{\star \star}$ \\
& $(.001)$ \\
\hline Source: TISS, AUDIT & $\left(\mathrm{p}^{*}\right)$ for a bilateral test
\end{tabular}

\section{DISCUSSION}

The present study permitted an analysis of the relations between antisocial behavior and alcohol consumption by school adolescents from Monterrey, Nuevo Leon, Mexico.

In the analysis of antisocial behavior according to gender, statistically significant differences were identified $(p<.001)$. It was observed that male adolescents $(\bar{X}=30.64, D E=16.26)$ present higher antisocial behavior rates than female adolescents $(\bar{X}=26.44, D E=15.85)$. Several international studies $^{(11-12)}$ coincide with these findings, as they also show gender differences in antisocial behavior and report higher mean scores of antisocial behavior for men.

These findings suggest that female students often tend to develop more prosocial than antisocial behaviors, as opposed to men. This can be explained by the biological factor, which provides women with an innate predisposition for empathy, which supposedly prepares women since a very early age to execute their care function, thus promoting higher levels of prosocial behavior. Furthermore, hormone changes significantly influence this result. Men present a relation between the increase in testosterone plasma levels and the increase in antisocial behavior, aggressiveness and irritability, which would inhibit their tendency to act in a prosocial way.

On the other hand, men and women present different standards of social development. Whereas negative assertion is promoted for men, women are taught to give preference to the needs of others, which results in the differences of sexual stereotypes in both genders' socialization process. No statistically significant age differences have been found for antisocial behavior. However, even though the difference was not enough to be significant, the study observed a higher mean level of antisocial behavior in 16-year-olds. These results coincide with previous studies $^{(11-12)}$, as they suggest that antisocial behavior in childhood and adolescence is a factor that predisposes to greater social inadaptation in adulthood. This highlights the importance of the early identification of antisocial behavior in the first stages of development, in order to prevent problems like drug consumption. No significant education differences were found in antisocial behavior.

Indications of gender differences in the alcohol consumption were found neither sometime in life nor over the last year. Nevertheless, gender differences in present alcohol consumption were observed $\left(\chi^{2}=4.54\right.$, $p=.033)$, showing that male adolescents consume alcohol to a greater extent (36.6\%) than female adolescents $(27.8 \%)$. Similarly to several studies ${ }^{(4,13)}$, the results show no gender differences in the consumption of alcoholic drinks sometime in life and in the last year. However, it is worth mentioning that another study ${ }^{(14)}$ presented substantial gender differences in alcohol consumption in the last month, and also that men consume more alcoholic drinks than women.

Highlighting the differences in alcohol consumption by adolescents, older adolescents, further advanced in education levels, also presented a higher proportion of alcohol consumption sometime in life, in the last year and in the last month. Several studies $^{(4,14-15)}$ agree with these findings and indicate that higher ages and education levels present higher proportions of alcohol consumption as well. Therefore, as adolescents grow older, they are more exposed to risks, since they participate in social meetings more often and face more pressure and stressful situations, which are considered risk factors for the use of alcohol.

Regarding the adolescents' education level, this study observed that, as this level advances, alcohol consumption by school adolescents also increases. These findings are consistent with findings from other studies ${ }^{(4,13-14)}$, which found education level differences, thus corroborating the fact that, as adolescents advance in their education level, they increase their consumption of alcoholic drinks, and also have to make more complex decisions.

According to the AUDIT score, the study observed that $34.7 \%$ of the adolescents present risk alcohol consumption, $14.8 \%$ report symptoms of alcohol dependence and $30.4 \%$ already manifest damage related to alcohol consumption. The AUDIT results did not present gender and education differences in alcohol consumption. Some findings differ from other studies developed with American adolescents $^{(16)}$, which reported gender and age differences in alcohol consumption. Besides, they also 
observed that, as adolescents grow older, their risks of alcohol consumption also increase.

As for the results of this study, the alarming increase in alcohol consumption by Mexican adolescents deserves attention, also because the purchase of this addictive substance is illegal for people under 18 years old. Some of the factors that may favor the consumption of alcoholic substances are the broadcasting of these substances by communication media and the lack of legal control on the commerce of alcoholic drinks.

The relation found between antisocial behavior and alcohol consumption $\left(r_{s}=.272, p<.001\right)$ in the school adolescents means that, the higher the antisocial behavior level, the higher the consumption of alcohol and illicit drugs by adolescents, similarly to the reports of studies developed ${ }^{(11)}$ with Spanish students, which indicate antisocial behavior as a predictive variable for alcohol consumption. By analyzing these results, it is observed that antisocial behavior appears as a risk factor that is highly related to the consumption of alcohol and other illicit drugs by school adolescents. Therefore, it is essential to consider this development stage also as a stage of vulnerability, in which several behaviors that can affect and entail consequences for their adult life are initiated.

\section{FINAL CONSIDERATIONS}

Considering the contribution of the present study, it is considered an educational proposal, aimed to promote and facilitate the development of social competence, behaviors and prosocial values, in order to prevent and correct antisocial behavior.

The authors consider that the study results may provide support for more accurate identification of the adolescents' social abilities and their relation to drugs consumption, with a view to designing more efficient educational actions.

It is worth mentioning that the findings of this study contribute to the generation of scientific Nursing knowledge, provided with a better perspective on the drugs phenomenon among the school adolescent population. In this sense, a multidimensional view of the problem will help to find the determining macro and micro factors that contribute to the presence of the problem. Therefore, it is important that, as more knowledge on the drugs phenomenon is generated, new operational models are developed to guide the creation of public policies, programs, research projects and interventions in the consumption of drugs, particularly for vulnerable population groups like adolescents.

\section{REFERENCES}

1. Consejo Nacional Contra las Adicciones-Secretaría de Salud (MX) [CONADIC-SS]. (2003). Encuesta Nacional de Adicciones 2002. México. [Acceso Marzo, 2003], Disponible en: www.conadic.gob.mx.

2. United Nations Office on Drugs and Crime [UNODC]. World Drug Report 2006, Volumen 1: Análisis. [Acceso 5 Diciembre], 2006. Disponible em: http://unodc.org

3. Fraile DCG, Riquelme PN, Pimenta CA. Consumo de Drogas lícitas e ilícitas en escolares y factores de protección y riesgo. Rev Latino-am Enfermagem; 2004, 12:345-51.

4. Villatoro-Velazquez J, Medina-Mora M, Hernández M, Fleiz C, Amador N, Bermúdez P. La encuesta de estudiantes de nivel medio y medio superior de la ciudad de México: Noviembre 2003. Prevalencias y Evolución del consumo de drogas. Rev Mex Salud Mental 2005; 28(1):38-50.

5. Dormitzer CM, Gonzalez GB, Pena M, Bejeranoc J, Obando, $P$, Sánchez $M$ et al. The PACARDO research project: youthful drug involvemnet in Central America and The Dominican Republic. Rev Panam Salud Publica 2004; 15(6):400-16.

6. National Institute On Drug Abuse [NIDA]. Previniendo el uso de drogas entre niños y adolescentes: Factores de riesgo y protección,[Acceso Febrero, 2003]. Disponible en http:// www.drugabuse.gov/Prevention/Spanish/factoresriesgo.
7. Del-Prette ZAP, Del-Prette A. Psicología Educacional e com adolescente em risco: prática na avaliação e promoção de habilidades sociais. Avaliação Psicológica 2006; 5(1):99-104. 8. Inglés $\mathrm{CJ}$, Hidalgo MD, Méndez FX, Inderbitzen HM. The Teenage Inventory of Social Skills: reliabity and validity of the Spanish Translation. Journal of Adolescence 2003; 26:505-10.

9. Sussman S, Unger JB, Dent CW. Peer group selfidentification among alternative high school youth: A predictor of their psychosocial functioning five years later. International J Clin Health Psychol 2004; 4:9-25.

10. Babor T, Higgins-Biddle J, Saunders JB, Monteiro MG. AUDIT, Cuestionario de Identificación de los trastornos debidos al consumo de alcohol: pautas para su utilización en atención primaria. Organización Mundial de la Salud [OMS], CH1211, Ginebra 27, Suiza, 2001: 1-40.

11. Ingles CJ, Delgado B, Bautista R, Torregosa MS, Espada JP, García-Fernandez JM et al. Factores Psicosociales relacionados con el consumo de alcohol y tabaco en adolescentes españoles. Int J Clin Health Psicol 2007; 7(2):403-420.

12. Duncan BC, Vanyukov M, Cornelius J. Childhood Antisocial Behaviour and Adolescent Alcohol Use Disorders. Alcohol Res \& Health 2002; 26(2):109-15.

13. Rueda LV, Malbergier M, De Andradde V, Guerra A. Fatores aasociado ao consumo de álcool e drogas entre estudantes universitarios. Rev Saúde Pública 2006; 40(2):280-8. 
14. Horta LR, Horta LB, Tavares PR, Neves SM. Tabaco, alcohol e outras drogas entre adolescentes em Pelotas, Rio Grande do Sul, Brasil: uma perspectiva de gênero. Cad Saúde Pública, 2007; 23(4):775-83.

15. Urquieta JE, Hernández M, Hernández B. El consumo de tabaco y alcohol en jóvenes de zonas urbanas marginadas de México. Un análisis de desiciones relacionadas. Salud Pública de México 2006; 48 (sup. 1):S30-S40.

16. Knight JR, Sherritt L, Harris SK, Gates EC, Chang G. Validity of brief alcohol screening test among adolescents: a comparison of AUDIT, POSIT, CAGE, and CRAFFT. Alcohol Clin Exp Res 2003; 27(1):67-73. 